DOI: https://doi.org/10.30749/2594-8261.v4n2p15-46

\title{
GESTÃO DOCUMENTAL E DA MEMÓRIA DO PODER JUDICIÁRIO: O PROGRAMA DO CONSELHO NACIONAL DE JUSTIÇA
}

\section{RECORDS MANAGEMENT AND MEMORY: THE NATIONAL COUNCIL OF JUSTICE'S PROGRAMME}

\section{Carlos Alexandre Böttcher Ingrid Schroder Sliwka ${ }^{\star \star}$}

Resumo: O objetivo principal do artigo é analisar a relevância do Programa Nacional de Gestão Documental e Memória do Poder Judiciário (Proname), instituído pelo Conselho Nacional de Justiça (CNJ). A metodologia adotada parte do levantamento das fontes primárias constitucionais e legais, que fundamentam o Programa, e prossegue com o exame dos atos normativos emanados pelo CNJ para apresentar seu desenvolvimento histórico. Em seguida, o texto realiza descrição e breve análise teórica das principais questões relacionadas ao tema e à sua regulamentação vigente. Também destaca a documentação histórica ou de guarda permanente como componente do Patrimônio Cultural Nacional. Por fim, apresenta uma síntese do estado atual do Programa com considerações e desafios para a Gestão Documental e da Gestão da Memória do Poder Judiciário.

Palavras-chave: Poder Judiciário. Gestão Documental. Gestão da Memória. Conselho Nacional de Justiça. Patrimônio Cultural.

Abstract: This paper's main goal is to analyse the importance of the "Records Management and Memory Programme" instituted by the Brazilian National Council of Justice. Its methodology departs from the constitutional and legal primary sources that support the Programme. Then it proceeds by examining the normative acts issued by the National Council of Justice to present the Programme's historical development. Further on, this paper makes a description and brief theoretical analysis of the main issues regarding the subject and its current regulation. It highlights as well the historical archives as part of the national cultural heritage. In the end, the paper summarizes today's state of affairs of the Programme establishing considerations and challenges for Records and Memory management in the Brazilian Judicial Branch.

Keywords: Judiciary. Records management. Memory. National Council of Justice (Brazil). Cultural heritage.

\footnotetext{
* Juiz de Direito do Tribunal de Justiça do Estado de São Paulo (TJ/SP). Doutor em História do Direito (Direito Civil) pela Faculdade de Direito da Universidade de São Paulo (USP). Mestre em História do Direito (Direito Civil) pela Faculdade de Direito da Universidade de São Paulo (USP). Especialista em Direito Romano pela Università di Roma La Sapienza, Itália. Juiz formador da Escola Paulista da Magistratura (EPM) E-mail: cbottcher@tjsp.jus.br

** Juíza Federal da 5 ${ }^{\mathbf{a}}$ Vara Federal de Porto Alegre (JFRS). Ex-membro do Comitê do Programa Nacional de Gestão Documental e Memória do Poder Judiciário (Proname) do CNJ. E-mail: sliwkaingrid@gmail.com
} 


\section{INTRODUÇÃO}

O presente artigo aborda a relevância do Programa Nacional de Gestão Documental e Memória do Poder Judiciário (Proname) do Conselho Nacional de Justiça (CNJ).

A metodologia adotada parte do levantamento das fontes primárias constitucionais e legais do Programa e prossegue com o exame dos principais atos normativos emanados pelo CNJ para apresentar seu desenvolvimento histórico. Em seguida, o texto realiza breve descrição e análise teórica das principais questões relacionadas à Gestão Documental e à Gestão da Memória.

A temática tem estreita fundamentação no direito constitucional de pleno acesso às informações constantes na documentação produzida e acumulada pelo Poder Judiciário, Como corolário desse direito, há o dever, também expressamente previsto na Constituição Federal, de preservação e divulgação das fontes da cultura nacional, do qual decorre a necessidade de adequada gestão de arquivos e de todos os elementos componentes do Patrimônio Cultural Nacional.

A estrutura e a trajetória normativa do Programa serão apresentadas a partir da sua instituição, que teve a base lançada em 2008 com a assinatura do termo de cooperação entre o Conselho Nacional de Justiça (CNJ), responsável pelo controle administrativo do Poder Judiciário e o Conselho Nacional de Arquivos (Conarq), competente para as políticas públicas de arquivos.

Com o enfoque especialmente na recente Resolução CNJ no 324 , de 30 de junho de 2020, serão examinados os principais fundamentos, princípios, diretrizes e normas estabelecidos para a Gestão Documental e a Gestão da Memória do Poder Judiciário brasileiro, com breve análise teórica de referências doutrinárias sobre o tema, destacando a documentação de guarda permanente ou histórica como componente do Patrimônio Cultural Nacional.

Por fim, o artigo apresentará a síntese dos principais aspectos abordados com algumas considerações e desafios para a efetiva implementação e desenvolvimento da temática no âmbito do Poder Judiciário brasileiro. 


\section{FUNDAMENTOS CONSTITUCIONAIS E LEGAIS}

A Gestão Documental e a Gestão da Memória, ${ }^{1}$ que são as principais vertentes de atuação do Programa Nacional do Conselho Nacional de Justiça (CNJ), encontram seus fundamentos na Constituição Federal, que prevê direitos e obrigações do Estado relacionados ao acesso à informação entre as Garantias Fundamentais (Título II), na Organização do Estado (Título III) e na disciplina da Ordem Social (Título VIII). (BRASIL, 1988).

O direito de acesso à informação, que é fundamental, garante a todos o recebimento dos órgãos públicos informações de seu interesse particular ou de interesse coletivo ou geral, ressalvadas apenas as hipóteses em que o sigilo seja imprescindível à segurança da sociedade e do Estado (artigo 5º, incisos XIV, XXXIII).

No título correspondente à Organização do Estado, a Constituição Federal, ao prever a participação dos usuários dos serviços na administração pública, estabeleceu o direito de acesso aos registros e informações sobre os atos do governo, o que também se aplica à atuação do Judiciário, enquanto Poder de Estado, no exercício de suas atividades (artigo 37, parágrafo 3ํㅜㄹ inciso II). 2

Ademais, no título atinente à Ordem Social, a Constituição prescreve que cabem à administração pública a gestão da documentação governamental, incluindose também a produzida e acumulada pelo Poder Judiciário no exercício de suas funções, e as providências para franquear sua consulta a quantos dela necessitem (artigo 216, parágrafo $2^{\circ}$ ).

Como se verá ao longo do texto, para observar os comandos constitucionais mencionados, a gestão da documentação judicial ou administrativa deve ter início antes mesmo de seu ingresso perante os diversos órgãos do Poder Judiciário, perpassando por todas as fases de produção, tramitação, arquivamento e avaliação, etapa em que se conclui a destinação dos documentos, seja para o descarte daqueles desnecessários e com finalidade cumprida, seja para a preservação dos históricos ou de guarda permanente.

E tais acervos documentais de guarda permanente ou histórica do Poder Judiciário fazem parte do Patrimônio Cultural brasileiro, assim como a memória,

\footnotetext{
${ }^{1}$ A Gestão Documental será analisada no item 4 e a Gestão da Memória no item 5 do presente trabalho. 2 Ainda que o conteúdo da norma faça referência direta à atuação administrativa, a partir das Leis $n^{\circ} \mathrm{s}$ 9.868/99 (BRASIL, 1999a), 9.882/99 (BRASIL, 1999b) e do Código de Processo Civil de 2015, houve previsão de maior participação do cidadão na formação do convencimento judicial por meio da realização de audiências públicas e pela instituição da figura do amicus curiae.
} 
cabendo ao Estado, com o apoio da comunidade, sua promoção e proteção (artigo 216, inciso IV e parágrafo $1^{\circ}$, da Constituição Federal).

Há rico Patrimônio Histórico e Cultural entre os bens materiais e imateriais dos órgãos da Justiça, que devem estar disponíveis a toda a sociedade, pois constituem relevantes fontes de pesquisa para a ciência e a cultura nacionais, às quais o Estado deve garantir o pleno acesso (artigo 215, da Constituição Federal).

Ademais, a guarda e a proteção desse Patrimônio são temas afetos à competência comum da União, dos Estados, do Distrito Federal e dos Municípios, que podem legislar de maneira concorrente sobre o tema (artigos 23, incisos III e IV, e 24, VII, da Constituição Federal).

Ao Conselho Nacional de Justiça, criado pela Emenda Constitucional n. 95 de 2004, compete o controle da atuação administrativa do Poder Judiciário (artigo, 103-B, parágrafo 4ํㅡㄹ da Constituição Federal). Na sua missão de aperfeiçoamento do sistema judiciário brasileiro, principalmente, no que concerne ao controle e à transparência administrativa e processual, incluem-se a coordenação e a normatização das políticas de Gestão Documental e da Memória. (BRASIL, 1988).

Portanto, é necessário situar essa temática pelo prisma constitucional e dos direitos fundamentais, pois ainda subsiste desconhecimento sobre a matéria e o relevante papel das atividades de Gestão Documental e da Memória como essenciais não só ao desempenho das atividades próprias do Poder Judiciário, mas também no contexto do Estado Democrático de Direito. Com efeito, essas atividades garantem o acesso às informações e respectiva preservação, seja para o exercício de direitos individuais, seja para a participação na administração pública, seja para o exercício dos direitos culturais.

Além da base constitucional, a matéria também é disciplinada por alguns diplomas normativos, tais como a Lei no 8.159/91 (BRASIL, 1991), que dispõe sobre a política nacional de arquivos; a Lei no 9.605/98 (BRASIL, 1998), que estabelece sanções penais e administrativas contra condutas e atividades lesivas ao meio ambiente cultural de que faz parte patrimônio arquivístico; a Lei n. $\stackrel{0}{11.419 / 06}$ (BRASIL, 2006), que regulamenta a informatização do processo judicial; a Lei no 12.527/11 (BRASIL, 2011), que disciplina o acesso à informação. Dentre as leis mencionadas, guardam especial interesse a primeira e a última.

A Lei no 8.159/91 (BRASIL, 1991), ao estabelecer a política nacional de arquivos públicos e privados, determina o dever de o Poder Público promover a gestão 
documental e a proteção especial a documentos de arquivos como instrumento de apoio à administração, à cultura e ao desenvolvimento científico e como elementos de prova e informação ${ }^{3}$.

A administração da documentação pública ou de caráter público compete às instituições arquivísticas federais, estaduais, do Distrito Federal e municipais, das quais também fazem parte os arquivos do Poder Judiciário nas respectivas esferas de competência federativa ${ }^{4}$.

Competem aos arquivos do Poder Judiciário Federal a gestão e o recolhimento dos documentos produzidos e recebidos no exercício de suas funções, a preservação e a disponibilização de acesso a tais documentos ${ }^{5}$, ao passo que a legislação estadual e distrital definirá os critérios de organização dos arquivos estaduais, dentre os quais aqueles do respectivo Poder Judiciário, com observância da Constituição Federal e da lei em questão ${ }^{6}$.

De sua parte, a Lei ํํ 12.527/11 (BRASIL, 2011) estabelece parâmetros concretos à implementação dos direitos e deveres constitucionais mencionados de acesso a informações de interesse particular, coletivo ou geral e relativas à organização do Estado. A lei em questão está diretamente relacionada às atividades de Gestão Documental, porquanto a devida organização da documentação, o gerenciamento de informação e a preservação do patrimônio arquivístico tornam "viável o acesso às informações necessárias à administração da justiça, ao exercício de direitos e da cidadania, bem como a elementos que compõem a memória nacional e institucional" (HENDGES; SLIWKA, 2013). A lei foi disciplinada pela Resolução CNJ 215/2015. (CONSELHO NACIONAL DE JUSTIÇA, 2015a).

Expostos os fundamentos constitucionais e legais atinentes à matéria, no item seguinte, será apresentada a trajetória do Programa desde sua criação, estrutura de seu funcionamento e os principais atos normativos relacionados.

\section{PROGRAMA NACIONAL DE GESTÃO DOCUMENTAL E MEMÓRIA DO PODER JUDICIÁRIO (PRONAME) DO CONSELHO NACIONAL DE JUSTIÇA}

No exercício das suas funções constitucionais de controle administrativo, o Conselho Nacional de Justiça atua por meio de ações, normas, planos e projetos a

\footnotetext{
${ }^{3}$ Artigo $1^{\circ}$, da Lei $n^{\circ} 8.159 / 91$.

${ }^{4}$ Artigo 17, da Lei ํㅜ 8.159/91.

${ }^{5}$ Artigo 20, da Lei no $8.159 / 91$.

${ }^{6}$ Artigo 21 , da Lei no $8.159 / 91$.
} 
fim de conferir efetividade à sua missão de garantidor da transparência e da eficiência do Poder Judiciário.

Dentre os programas do Conselho com tal finalidade, destacam-se a Gestão Estratégica e Planejamento, a Gestão Processual, a Gestão de Tecnologia da Informação e Comunicação.

O Programa Nacional de Gestão Documental e Memória, objeto do presente artigo, tem por escopo disciplinar a atividade dessas áreas para todos os órgãos do Poder Judiciário. Como resultado, garantem-se o acesso efetivo a informações necessárias ao exercício de direitos, a participação do cidadão na administração pública e o acesso ao Patrimônio Cultural constante de arquivos, bibliotecas, museus e unidades de memória. Por fim, trata-se de ações indispensáveis à transparência, eficácia e efetividade das funções administrativas e jurisdicionais, auxiliando a tomada de decisões pelo próprio Poder Judiciário.

\subsection{Início}

O Programa Nacional de Gestão Documental e Memória do Poder Judiciário (Proname) foi lançado em 12 de dezembro de 2008, em ato solene no Arquivo Nacional, por meio da celebração de acordo de cooperação técnica entre o Conselho Nacional de Justiça (CNJ) e o Conselho Nacional de Arquivos (Conarq). (CONSELHO NACIONAL DE ARQUIVOS, 2008a; CONSELHO NACIONAL DE JUSTIÇA, 2008a).

O Conarq, vinculado ao Arquivo Nacional, é composto por representantes dos Poderes Executivo, Legislativo e Judiciário e membros da sociedade civil. Tem por finalidade definir a política nacional de arquivos públicos e privados, enquanto órgão central do Sistema Nacional de Arquivos - SINAR, também integrado pelos arquivos dos três poderes ${ }^{7}$.

Dentre outras atribuições, compete ao Conarq estabelecer diretrizes para o funcionamento do SINAR, visando à gestão, à preservação e ao acesso aos

\footnotetext{
7 O Conarq foi criado pelo artigo 26, da Lei 8.159/91 (BRASIL, 1991) e regulamentado pelo Decreto 4.073/2002 (BRASIL, 2002), cujo artigo 3을 disciplina sua composição. O artigo 12, por sua vez, elenca os integrantes do SINAR: I - o Arquivo Nacional; II - os arquivos do Poder Executivo Federal; III - os arquivos do Poder Legislativo Federal; IV - os arquivos do Poder Judiciário Federal; $V$ - os arquivos estaduais dos Poderes Executivo, Legislativo e Judiciário; VI - os arquivos do Distrito Federal dos Poderes Executivo, Legislativo e Judiciário; VII - os arquivos municipais dos Poderes Executivo e Legislativo.
} 
documentos de arquivos; zelar pelo cumprimento dos dispositivos constitucionais e legais, que norteiam o funcionamento e o acesso aos documentos de arquivo; propor atos normativos necessários ao aprimoramento e à implementação da política nacional de arquivos públicos e privados; estimular programas de gestão e de preservação de documentos públicos; estimular a implantação de sistemas de arquivos nos Poderes Executivo, Legislativo e Judiciário.

O Termo de Cooperação Técnica firmado entre CNJ e Conarq foi motivado em grande parte pela Resolução Conarq 26/2008, que estabeleceu diretrizes básicas de gestão de documentos para adoção pelos arquivos do Poder Judiciário, remetendo a regulamentação ao primeiro. (CONSELHO NACIONAL DE ARQUIVOS, 2008b).

A cooperação técnica teve vigência de doze meses e tinha como objeto o desenvolvimento de ações integradas com o foco na implementação de política pública nacional de Gestão Documental e Memória do Poder Judiciário, com os seguintes objetivos:

I. promover proteção especial aos documentos de arquivo; II. padronizar as práticas e instrumentos de gerenciamento arquivístico, contemplando a harmonização dos prazos de guarda e a destinação final dos documentos de arquivo produzidos e recebidos pelos órgãos do Poder Judiciário; III. fomentar as atividades de gerenciamento dos acervos (judiciais ou administrativos), com vista à redução de custos; IV. promover a cooperação técnica entre os Tribunais de Justiça em questões que envolvam o gerenciamento do acervo arquivístico judicial; V. propiciar acesso e celeridade no atendimento dos consulentes dos arquivos judiciais; VI. preservar e divulgar os documentos históricos do Poder Judiciário. (CONSELHO NACIONAL DE JUSTIÇA, 2008a).

Como se verá ao longo do presente artigo, houve significativos avanços em relação aos objetivos traçados na época, mas ainda existem muitas ações a empreender, como revela recente diagnóstico publicado sobre os arquivos do Poder Judiciário. (CONSELHO NACIONAL DE JUSTIÇA, 2020a).

\subsection{Organização}

O Proname é coordenado por um Comitê, criado em 2009 (CONSELHO NACIONAL DE JUSTIÇA, 2009a), composto por representantes de todos os segmentos do Poder Judiciário, do próprio CNJ e do Conarq. (CONSELHO NACIONAL DE JUSTIÇA, 2015b, 2018).

${ }^{8}$ Artigo $2^{\circ}$, do Decreto 4.073/2002 (BRASIL, 2002), com a redação dada pelo Decreto 10.148/2019. (BRASIL, 2019a). 
O Comitê tem importante papel para o desenvolvimento das políticas de Gestão Documental e Memória, tendo como atribuições: a) elaborar, atualizar e publicar no portal do CNJ os instrumentos de gestão documental e de gestão da memória; b) encaminhar proposições complementares ao programa para apreciação do CNJ; c) propor e apoiar ações de capacitação de servidores e magistrados em questões relacionadas ao programa; d) acompanhar a aplicação do Programa, sugerindo medidas, que entender necessárias ao CNJ. (CONSELHO NACIONAL DE JUSTIÇA, 2020b) ${ }^{9}$.

Recentemente, a representatividade do Comitê foi ampliada com a previsão de participação de cinco magistrados de qualquer Tribunal com experiência em Gestão Documental e Gestão da Memória, de modo a incentivar maior envolvimento dos juízes nessas questões relevantes para o Poder Judiciário. Também foram incluídos dois membros dos Tribunais Regionais Federais e dos Tribunais Regionais do Trabalho. No tocante aos representantes dos Tribunais, além da experiência, deverá ser observada a participação de profissionais com formação em História e Arquivologia, importantes áreas para a temática ${ }^{10}$.

O Programa também alcançou significativo fortalecimento institucional com a criação da Comissão Permanente de Gestão Documental e de Memória do Poder Judiciário composta por, no mínimo, três membros Conselheiros. Dentre seus objetivos principais, estão zelar pela observância do Programa e propor, em coordenação com o Comitê, diretrizes para a gestão documental e para a preservação e difusão da memória institucional e do patrimônio cultural e arquivístico do Poder Judiciário. (CONSELHO NACIONAL DE JUSTIÇA, 2019).

Nos próximos itens, veremos os principais atos normativos relacionados ao Programa, que demonstram seu desenvolvimento e estado atual.

\subsection{Normatização Inicial (Recomendações CNJ 37/2011 e 46/2013)}

Como resultado do trabalho inicial do Comitê do Proname, foi apresentada minuta para disciplina normativa do Programa, que resultou na edição da Recomendação CNJ 37/2011, centrada em estabelecer os princípios, diretrizes e instrumentos do Programa voltados à gestão documental e no estabelecimentos de

\footnotetext{
${ }^{9}$ Artigo 8ㅜㄹ, da Resolução CNJ 324/2020.

${ }^{10}$ Artigo 9, incisos XI, XII e XIV, da Resolução CNJ 324/2020.
} 
critérios mínimos para avaliação de documentos, com base em alguns pilares de preservação pré-estabelecidos. (CONSELHO NACIONAL DE JUSTIÇA, 2011a).

Até a edição da Recomendação CNJ 37/2011, não havia em relação ao Poder Judiciário nacional regramento geral e específico sobre a matéria. (SLIWKA, 2011a).

Com a promulgação da Lei ํo 8.159/91, tratada no item 2 acima, foi expressamente prevista a possibilidade de eliminação de documentos produzidos por instituições públicas e de caráter público, mediante autorização da instituição arquivística, na esfera de competência própria. (BRASIL, 1991).

O descarte de processos judiciais arquivados, que é um dos resultados das atividades de avaliação documental inerentes à gestão, havia sido disciplinado anteriormente pelo artigo 1.215, do Código de Processo Civil de 1973 (BRASIL, $1973)^{11}$. No entanto, esse dispositivo não estabelecia critérios de aferição do valor secundário da documentação e desconsiderava os prazos prescricionais de guarda dos processos superiores a cinco anos contados do arquivamento. Foi suspenso pelo artigo 1ㄹ, da Lei oㅜ 6.246/75 até que lei especial disciplinasse a matéria (BRASIL, 1975). Em julgamento posterior, versando sobre assunto correlato, considerou-se que o artigo legal suspenso tratava de matéria estranha ao processo civil e que o descarte de processos não podia prescindir de adequada avaliação para seleção da documentação de guarda permanente. (SUPREMO TRIBUNAL FEDERAL, 2003).

A Recomendação representou notável avanço na matéria, servindo de base para a instituição das políticas próprias dos vários órgãos, em razão do escasso regramento então existente para a Gestão Documental do Poder Judiciário, mesmo após a vigência da lei mencionada ${ }^{12}$.

Previu os procedimentos e as cautelas para o descarte dos documentos com finalidade cumprida e que não fossem destinados para guarda permanente, além da instituição de Comissões Permanentes de Avaliação Documental.

\footnotetext{
11 O Art. 1.215 do CPC de 1973 dispunha: Os autos poderão ser eliminados por incineração, destruição mecânica ou por outro processo adequado, findo o prazo de cinco (5) anos, contados da data do arquivamento, publicando-se previamente no órgão oficial e em jornal local, onde houver, aviso aos interessados, com o prazo de trinta (30) dias. $\$ 1$ ó lícito, porém, às partes e aos interessados requerer, às suas expensas, o desentranhamento dos documentos que juntaram aos autos, ou a microfilmagem total ou parcial do feito. $\S 2^{\circ}$ Se, a juízo da autoridade competente, houver, nos autos, documentos de valor histórico, serão eles recolhidos ao Arquivo Público.

${ }^{12} \mathrm{Em}$ alguns diplomas legais específicos, havia previsão de descarte de autos findos, como na Lei no 7.627/87 (BRASIL, 1987), que dispunha sobre a eliminação de autos nos órgãos da Justiça do Trabalho, e na Lei no 783/98 (RONDÔNIA, 1998), do Estado de Rondônia, que continha idêntica possibilidade. No entanto, tais previsões não se faziam acompanhadas do necessário regramento do procedimento de avaliação inerente ao desempenho dessa atividade, o que é imprescindível para que o descarte de documentação.
} 
Houve evolução do Programa com a edição da Recomendação CNJ 46/2013 (CONSELHO NACIONAL DE JUSTIÇA, 2013), que previu a possibilidade de apresentação de proposta de guarda permanente pelas entidades de caráter histórico, cultural e universitário e a celebração de convênios com tais entidades para auxílio nas atividades de Gestão Documental ${ }^{13}$.

Posteriormente, somente neste ano de 2020, houve substancial alteração dos normativos do Programa com a edição das Resoluções CNJ 316 e 324/2020. examinadas nos itens seguintes.

\subsection{Normatização Atual (Resoluções CNJ 316/2020 e 324/2020)}

O Programa teve avanço formal em relação à Memória, com a edição da Resolução CNJ 316/2020 (CONSELHO NACIONAL DE JUSTIÇA, 2020c), que instituiu o 10 de maio como Dia da Memória do Poder Judiciário.

A data comemorativa foi criada em razão da importância da Memória como parte do Patrimônio Cultural brasileiro. O Poder Judiciário, no exercício de suas funções, acompanha as transformações políticas, sociais, econômicas, culturais e tecnológicas da sociedade ao longo dos anos, o que se espelha em seus bens materiais e imateriais, muitos dos quais objeto de acervos arquivísticos, biblioteconômicos e museológicos. Desse modo, a preservação desses bens e sua difusão são fundamentais para conhecimento tanto da história da Justiça, quanto do próprio país.

A criação de data específica apresenta três objetivos principais: contribuir para a consolidação da identidade do Poder Judiciário perante a sociedade; dar maior visibilidade à Memória da Justiça brasileira e à importância de resgate, preservação, valorização e divulgação do seu Patrimônio histórico; reforçar a noção de pertencimento de juízes e servidores à instituição. (BÖTTCHER, 2020a, p. 14-17, 2020b).

A proposta da criação do Dia da Memória do Poder Judiciário foi formulada inicialmente na rede Memojus Brasil e votada por seus integrantes, que são profissionais e especialistas da área de vários Tribunais e órgãos públicos do país,

13 Também foi autorizado o descarte de agravos de instrumentos, recursos em sentido estrito em matéria criminal processados por instrumento e incidentes processuais autuados em apartado imediatamente após o traslado das peças originais não existentes no processo principal e sem necessidade de publicação de edital de eliminação. Foi dispensada, também, a preservação de amostra estatística em relação aos documentos administrativos. 
antes de ser encaminhada ao Comitê do Proname. (BÖTTCHER, 2020a, p. 20-24, 2020c, p. 2-3).

A data escolhida faz referência ao alvará de 10 de Maio de 1808 de D. João $\mathrm{VI}$, que criou a Casa da Suplicação do Brasil no Rio de Janeiro, marco representativo na história do Poder Judiciário nacional por simbolizar espécie de independência da Justiça brasileira em relação à portuguesa, pois a partir de então grande parte dos recursos não mais foi encaminhada a Lisboa para julgamento.

Para celebrar o Dia da Memória, os diversos órgãos do Poder Judiciário envidarão esforços de mobilização dos respectivos setores envolvidos de Museus, Arquivos, Memoriais, Bibliotecas, Comissões de Memória ou equivalentes, Unidades de Gestão Documental e afins, mediante o fomento de várias atividades, além da realização anual de Encontro Nacional de Memória do Poder Judiciário incentivado pelo CNJ. ${ }^{14}$

Muito embora a Resolução tenha sido publicada poucos dias antes do dia 10 de Maio de 2020, em situação de trabalho remoto em grande parte dos órgãos públicos do país, observou-se intensa mobilização dos Tribunais brasileiros para comemorar a data, corroborando a importância da instituição do ato normativo. (CONSELHO NACIONAL DE JUSTIÇA, 2020d, 2020e) $)^{15}$.

A Resolução CNJ 324/2020 (CONSELHO NACIONAL DE JUSTIÇA, 2020b), por sua vez, trouxe importantes avanços e novidades para a Gestão Documental e a Gestão da Memória do Poder Judiciário. Em razão da natureza de Resolução do ato aprovado, a disciplina da matéria adquire caráter obrigatório aos Tribunais do país, então inexistente na anterior Recomendação. (BÖTTCHER, 2020d).

A norma recente sintetiza o amadurecimento e a expansão do Programa Nacional de Gestão Documental e Memória do Poder Judiciário do CNJ, o qual é sistematizado de forma abrangente.

Além da integração do Comitê na própria estrutura do Programa, foram contempladas as evoluções legislativas sobre a matéria e houve ampliação do regramento da Gestão de documentos, com ênfase nos digitais, considerando a crescente utilização dos processos eletrônicos nos últimos anos. Pela primeira vez, a Gestão da Memória veio a ser disciplinada, de forma ordenada, por diretrizes e regras.

\footnotetext{
${ }^{14}$ Artigos 2ํㅜ e 3o, da Resolução CNJ 316/2020.

15 Deve ser realçada a oportunidade de reforço às ações museológicas do Poder Judiciário para celebração do Dia da Memória (10 de Maio) em razão da proximidade com o Dia Internacional dos Museus (18 de Maio), que é comemorado a partir de coordenação da Semana Nacional dos Museus pelo Instituto Brasileiro de Museus. (IBRAM, 2020).
} 
Pela relevância da nova Resolução para o Programa do CNJ, além das novidades já mencionadas ao longo do texto, nos itens seguintes, analisaremos a Gestão Documental, a Gestão da Memória e a guarda permanente ou histórica, separadamente, pois relacionada a ambas.

\title{
4 GESTÃO DOCUMENTAL
}

Inicialmente, é necessário destacar a importância dos Arquivos nas próprias instituições e para a sociedade, pois, não raras vezes, suas atribuições são pouco compreendidas. Essa importância é bem exemplificada na definição a seguir.

\begin{abstract}
Arquivos registram decisões, ações e memórias. Arquivos são um patrimônio único e insubstituível transmitido de uma geração a outra. Documentos de arquivo são geridos desde a criação para preservar seu valor e significado. Arquivos são fontes confiáveis de informação para ações administrativas responsáveis e transparentes. Desempenham um papel essencial no desenvolvimento das sociedades ao contribuir para a constituição e salvaguarda da memória individual e coletiva. O livre acesso aos arquivos enriquece o conhecimento sobre a sociedade humana, promove a democracia, protege os direitos dos cidadãos e aumenta a qualidade de vida. (UNESCO, 2010).
\end{abstract}

Uma das principais funções dos Arquivos é a Gestão Documental, que é definida como o conjunto de procedimentos e operações técnicas referentes à produção, à tramitação, ao uso, à avaliação e ao arquivamento dos documentos e processos recebidos pelo Poder Judiciário no exercício de suas atividades, inclusive administrativas, independentemente do suporte de registro da informação ${ }^{16}$.

Seus objetivos são possibilitar o integral exercício de direitos, manter as informações relevantes às partes e à instituição ao longo do tempo, realizar descarte seguro da documentação não mais necessária e preservar o Patrimônio Histórico. (SLIWKA, 2011b).

Para que tais objetivos sejam alcançados, a gestão começa antes do ingresso ou da produção da documentação, judicial ou administrativa, física ou eletrônica, por meio de sistemas informatizados aderentes ao Modelo de Requisitos para Sistemas Informatizados de Gestão de Processos e Documentos do Poder Judiciário - MoreqJus (CONSELHO NACIONAL DE JUSTIÇA, 2009a, 2009b) ${ }^{17}$, da utilização de Tabelas

\footnotetext{
${ }^{16}$ Artigo 2, inciso I, da Resolução CNJ 324/2020.

17 O Modelo de Requisitos para Sistemas Informatizados de Gestão de Processos e Documentos do Poder Judiciário (Moreq-Jus) contempla requisitos estabelecidos com o escopo de garantir a segurança, a preservação e a interoperabilidade com outros sistemas. Baseado em modelo europeu, - Moreq-Jus observa recomendações de Carta da UNESCO para Preservação do Patrimônio
} 
Processuais e Administrativas aplicáveis a todo o Poder Judiciário, os quais são instrumentos do Programa $^{18}$. No caso de processos judiciais, há utilização de numeração única. (CONSELHO NACIONAL DE JUSTIÇA, 2008b).

Os documentos são classificados, segundo a teoria das três idades, em correntes, intermediários e permanentes ${ }^{19}$.

A primeira delas é a dos arquivos correntes, nos quais estão abarcados os documentos durante seu uso funcional, administrativo, jurídico, em sua tramitação legal, os quais têm o uso relacionado às razões pelas quais foram criados. A segunda idade do arquivo intermediário é aquela em que os documentos já ultrapassaram seu prazo de validade jurídico-administrativa, mas ainda podem ser utilizados pelo produtor. (BELLOTTO, 2006, p. 24).

$\mathrm{Na}$ primeira e segunda fases, portanto, a ênfase está em garantir acesso e preservação da documentação pelo tempo necessário ao exercício de direitos. Em razão disso, as Tabelas de Temporalidade da Documentação foram construídas a partir do tempo necessário ao completo exercício de direitos e, no caso dos processos judiciais, considerando os prazos de prescrição, da revisão criminal e da ação rescisória.

$\mathrm{Na}$ última fase, quando a documentação não se faz mais necessária para os fins que geraram sua tramitação judicial ou administrativa, podem remanescer outros interesses para guarda, situação em que se torna permanente, não podendo ser eliminada e nem substituído o seu suporte originário por outro²0.

A operação denominada recolhimento conduz os documentos a um local de preservação definitiva, que são os arquivos permanentes. Ultrapassada a função primária do documento, iniciam-se seus usos científico, social e cultural. (BELLOTTO, 2006, p. 24).

Por meio do procedimento de avaliação, são analisados documentos e processos com o fim de verificar os prazos de guarda e a destinação final, de acordo com a atribuição de valores primários e secundários ${ }^{21}$.

Arquivístico Digital, que incentiva políticas públicas, metodologias e normas, que assegurem a autenticidade, integridade e acesso contínuo dos documentos digitais ao longo do tempo.

${ }_{18}$ Artigo 5, II e III, da Resolução CNJ 324/2020.

${ }^{19}$ Artigo 16, da Resolução CNJ 324/2020 utiliza a terminologia da teoria das três idades.

$20 \mathrm{O}$ artigo 29, parágrafo único, da Resolução CNJ 324/2020 dispõe: É vedada a eliminação de documentos e processos de guarda permanente, mesmo após microfilmagem, digitalização ou qualquer outra forma de reprodução ou reformatação.

${ }^{21} \mathrm{O}$ artigo 18, parágrafos $1^{\circ}$ e 2을 , da Resolução CNJ 324/2020 define os valores primário e secundário dos documentos. 
Os valores inerentes aos documentos arquivísticos modernos são dessas duas categorias: primários para a própria entidade de onde se originam e secundários para outras entidades ou usuários privados. Esses documentos nascem do cumprimento dos objetivos para os quais determinado órgão foi criado, tais como administrativos, fiscais, executivos. Esses usos são da sua importância inicial. Contudo, os documentos públicos são preservados em arquivos por apresentarem valores, que persistirão por muito tempo depois de cessado seu uso corrente e porque tais valores serão de interesse para usuários diversos daqueles originais. (SCHELLENBERG, 2006, p. 180).

Como resultado da avaliação, é separada a documentação sujeita a descarte daquela permanente elencada pelo artigo 30, da Resolução CNJ 324/2020 (CONSELHO NACIONAL DE JUSTIÇA, 2020b). Embora esses procedimentos sejam inerentes à Gestão Documental, o resultado deles interessa à Gestão da Memória, já que se trata da documentação histórica. Por essa razão e por sua importância, será tratada em item específico abaixo.

Finda a avaliação e observados os procedimentos da norma, é possível a eliminação de documentos destituídos do mencionado valor secundário. (CONSELHO NACIONAL DE JUSTIÇA, 2011b) 22 .

Se a documentação passível de eliminação for relacionada à atividade jurisdicional, devem ser salvaguardados os dados necessários à expedição de certidão sobre o conteúdo da decisão transitada em julgado. Por fim, a eliminação deve observar critérios de sustentabilidade social, ambiental e econômica, com garantia de que a descaracterização dos documentos não possa ser revertida.

Todo esse procedimento deve ser acompanhado pelas Comissões Permanentes de Avaliação Documental, a quem compete propor instrumentos arquivísticos de classificação, temporalidade e destinação; orientar a realização das atividades de análise a avaliação documental; identificar, definir e zelar pela aplicação dos critérios de valor secundário na documentação; analisar os editais de eliminação de documentos e processos e aprová-los ${ }^{23}$.

22 O descarte de documentos ocorre mediante a observância de critérios explanados pelo Manual de Gestão Documental do Poder Judiciário, importante instrumento do Proname e que se encontra em revisão para adequação à Resolução CNJ 324/2020.

${ }^{23}$ Compete também às CPADs a realização de estudos e encaminhamento de propostas ao Comitê do Proname sobre questões relativas à Gestão Documental e à Gestão da Memória, conforme artigo 11, da Resolução CNJ 324/2020. Recentemente, o Decreto Federal 10.148, de 2 de dezembro de 2019 determinou a instituição dessas Comissões Permanentes de Avaliação Documental a todos os órgãos e entidades da Administração Pública Federal. 
Para que as Comissões tenham representatividade e para que possam atuar de forma técnica e transdisciplinar, sua composição deve representar as diversas áreas de atuação institucional nesta matéria, com composição mínima de servidores responsáveis pela unidade de gestão documental e pelas atividades de Memória da instituição, servidores da unidade de tecnologia da informação e graduados em curso superior de Arquivologia, História e Direito. Essa composição fortalece a participação de olhares diversos a enriquecer as ações da CPAD. Preferencialmente. sua coordenação deve ser atribuída a magistrado com experiência em Gestão Documental ou da Memória24.

Importante novidade da Resolução é a referência expressa à Gestão de Documentos Digitais, os quais representam grande parte daqueles em trâmite nos Tribunais, sobretudo em relação aos processos judiciais. (CONSELHO NACIONAL DE JUSTIÇA, 2020b).

Cada órgão do Poder Judiciário deverá elaborar e publicar sua política de Gestão Documental de processos e documentos em meio digital, de acordo com as normativas do CNJ, prevendo-se a obrigatoriedade da existência de módulos de gestão de documentos, que contemplem, no mínimo, os planos de classificação e tabelas de temporalidades ${ }^{25}$.

A transformação digital é realidade em grande parte do mundo e no Brasil. Contudo, em geral, o tema da preservação digital ainda não tem recebido a devida atenção no país, o que é necessário em razão da rápida obsolescência das tecnologias e da ausência de segurança e de estratégias de preservação de muitas delas, que são substituídas por outras em curtos espaços de tempo, muitas vezes incompatíveis com as anteriores.

Nesse sentido, avanço importante foi a obrigatoriedade de adoção de Repositório Arquivístico Digital Confiável (RDC-Arq) pelos órgãos do Poder Judiciário, desenvolvido como software livre, gratuito e de código aberto, projetado para manter os dados em padrões adequados para a preservação digital e o acesso em longo prazo $^{26}$.

O termo RDC-Arq foi criado com a Resolução Conarq no 43/2015, que estabelece diretrizes para a implementação de Repositórios Arquivísticos Digitais Confiáveis para o arquivamento e manutenção de documentos digitais em suas fases

\footnotetext{
${ }^{24}$ Artigos 12 e 14, da Resolução CNJ 324/2020.

25 Artigos 31 e 32, da Resolução CNJ 324/2020.

26 Artigo 34, da Resolução CNJ 324/2020.
} 
corrente, intermediária e permanente dos órgãos e entidades integrantes do Sistema Nacional de Arquivos - SINAR, visando à preservação do Patrimônio Arquivístico Digital Brasileiro. (CONSELHO NACIONAL DE ARQUIVOS, 2015).

É importante olhar para o RDC-Arq, ou seja, para o Arquivo Permanente digital, como o lugar necessário e obrigatório perante a Lei 8159/91 para os documentos históricos/permanentes, e o lugar onde são implementados, hoje, os referenciais consolidados e atuais de uma Preservação Digital Sistêmica. (GAVA; FLORES, 2020).

Para ser efetiva e seguramente arquivado, o documento eletrônico deve ingressar em ambiente de RDC-Arq com vários requisitos e com observância da cadeia de custódia ininterrupta, a qual é importante na implantação dos sistemas informatizados para gestão, arquivamento e acesso de documentos digitais, conferindo-Ihe preservação ao longo do tempo. (FLORES; ROCCO; SANTOS, 2016).

Esse desafio é enorme e ao mesmo tempo fundamental para o Poder Judiciário brasileiro, que ainda não dispõe de sistemas com todos os requisitos indicados de Repositório Arquivístico Digital Confiável (RDC-Arq), o qual permite o arquivamento dos documentos eletrônicos em ambiente seguro, que é necessário para preservação daqueles destinados à guarda permanente ou histórica e respectivo acesso futuro, No entanto, existem iniciativas em andamento para sua implementação em alguns Tribunais brasileiros. (TRIBUNAL DE JUSTIÇA, 2018; SUPERIOR TRIBUNAL DE JUSTIÇA, 2019). O RDC-Arq foi também previsto para o acervo digital relacionado à memória institucional do órgão, como se verá no item seguinte.

A conversão de suporte do documento é permitida ${ }^{27}$. Contudo, tal autorização deve ser lida em consonância com o artigo 29, parágrafo único, da Resolução CNJ 324/2020, que veda a eliminação de documentos e processos de guarda permanente ou históricos, mesmo após microfilmagem, digitalização ou qualquer outra forma de reprodução 28 .

\section{GESTÃO DA MEMÓRIA}

Além de ser fenômeno individual e psicológico, a memória também pode resultar de uma entidade coletiva, seja um grupo, seja a própria sociedade

${ }^{27}$ Artigos 35 e 36, da Resolução CNJ 324/2020 e Lei no 11.419/2006. (BRASIL, 2006).

28 Nesse mesmo sentido, o artigo 2-A, parágrafo primeiro, da Lei no 12.682/12 (BRASIL, 2012), com a redação dada pela Lei no 13.874/19 (BRASIL, 2019b), regulamentada pelo Decreto 10.278, de 18 de março de 2020 (BRASIL, 2020), cujo artigo 9- veda o descarte dos documentos digitalizados, que apresentem conteúdo de valor histórico, ou seja, de guarda permanente. 
(HALBWACHS, 1990, p. 31-34). As famílias, os grupos sociais organizados, as instituições e as nações tendem a construir um passado, que seleciona e idealiza certos eventos e acontecimentos, afastando outros (DORTIER, 2010, p. 394-395). Tendo esse viés coletivo, a memória é objeto de atenção do Estado, que produz diversos tipos de documento, constrói a escrita e acumula objetos representativos com o fim de conservar os registros dos fatos pretéritos. (LE GOFF, 2003, p. 419).

A evolução das sociedades a partir da segunda metade do século $X X$ tem demonstrado a importância do papel desempenhado pela memória coletiva. Ao superar a história como ciência e como culto público, a memória coletiva faz parte das principais questões das sociedades desenvolvidas e em vias de desenvolvimento, representando um rico reservatório de arquivos, documentos e monumentos, além de ser elemento essencial da identidade, cuja busca é uma das atividades fundamentais das sociedades atuais. (LE GOFF, 2003, p. 469).

Conforme visto, a memória faz parte do Patrimônio Cultural brasileiro (artigo 216, da Constituição Federal) e tem natureza de direito fundamental. O Patrimônio Cultural é composto por bens materiais e imateriais, que expressam a criatividade de determinado povo: a língua, os ritos, as crenças, os lugares e monumentos históricos, a cultura, as obras de arte, os arquivos e bibliotecas. (IPHAN, 1985).

No âmbito do Poder Judiciário, esses bens, materiais ou imateriais, móveis ou imóveis, presentes em arquivos, bibliotecas, museus, memoriais, centros culturais contemplam fatos marcantes de sua história e da sociedade brasileira ao longo do tempo, pois a Justiça acompanha as transformações políticas, sociais, científicas, econômicas, tecnológicas e culturais do país.

A respeito da multiplicidade de temas relacionados à Memória, aos Patrimônios arquivístico, cultural e histórico, há inúmeros atos normativos da UNESCO, tais como a Convenção para a Proteção do Patrimônio Mundial Cultural e Ambiental de 1972 (UNESCO, 1972); Recomendação para a Salvaguarda e Preservação das Imagens em Movimento de 1980 (UNESCO, 1980); Convenção para a Salvaguarda do Patrimônio Cultural Imaterial de 2003 (UNESCO, 2003a); Carta sobre a Preservação do Patrimônio Digital de 2003 (UNESCO, 2003b); Declaração de Varsóvia: Cultura, Memória e Identidades de 2011 (UNESCO, 2011a); Declaração Universal sobre Arquivos de 2011 (UNESCO, 2011); Recomendação relativa à Proteção do Patrimônio Documental, incluso o Patrimônio Digital, e respectivo acesso de 2015 (UNESCO, 2015a) e Recomendação relativa à Proteção e Promoção dos 
Museus e Coleções, sua Diversidade e seu Papel na Sociedade de 2015. (UNESCO, 2015b).

Reconhecendo essa importância da Memória para o Poder Judiciário e para o país, pela primeira vez, o Conselho Nacional de Justiça sistematizou a sua gestão, trazendo diretrizes, princípios e regras. (CONSELHO NACIONAL DE JUSTIÇA, 2020b).

A Gestão da Memória é definida como o conjunto de ações e práticas de preservação, valorização e divulgação da história contida nos documentos, processos, arquivos, bibliotecas, museus, memoriais, personalidades, objetos e imóveis do Poder Judiciário, abarcando iniciativas direcionadas à pesquisa, à conservação, à restauração, à reserva técnica, à comunicação, à ação cultural e educativa ${ }^{29}$.

Os objetivos principais da Gestão da Memória contêm duas vertentes interrelacionadas. De um lado, a consolidação da identidade institucional do Poder Judiciário como pacificador social e garantidor da cidadania e dos direitos e o seu fortalecimento como um dos principais pilares do Estado Democrático de Direito. De outro lado, o resgate, a preservação, a valorização e a divulgação dos bens culturais e da história do Poder Judiciário integrantes do Patrimônio Cultural Nacional.

Cabe ao Conselho Nacional de Justiça, com o auxílio do Comitê do Proname, coordenar as iniciativas para fortalecimento e valorização da memória institucional do Poder Judiciário, promover a construção de redes nessa área entre os vários órgãos, o intercâmbio de experiências e de boas práticas, a implantação de sistemas e a colaboração mútua com o escopo de divulgação de seu patrimônio histórico e documental ao público e aos pesquisadores ${ }^{30}$.

Para implementação de política de Gestão da Memória em cumprimento aos preceitos constitucionais, a Resolução CNJ 324/2020 prevê princípios e diretrizes em dois artigos a seguir transcritos:

Art. 3o Os órgãos do Poder Judiciário devem observar as normas de Gestão Documental e de Gestão de Memória definidas no Proname, o qual é regido pelos seguintes princípios e diretrizes:

(...)

II. promoção da cidadania por meio do pleno acesso ao patrimônio arquivístico, bibliográfico, museográfico, histórico e cultural gerido e custodiado pelo Poder Judiciário;

III. produção da narrativa acerca da história do Poder Judiciário e a consequente difusão e consolidação da imagem institucional;

IV. intercâmbio e interlocução com instituições culturais e protetoras do Patrimônio Histórico e Cultural e da área da ciência da informação;

${ }^{29}$ Artigo 20, inciso II, da Resolução CNJ 324/2020.

${ }^{30}$ Artigo 37, da Resolução CNJ 324/2020. 
V. interface multidisciplinar e convergência dos saberes ligados às áreas da memória, da história e do patrimônio com aquelas da museologia, da arquivologia, do direito, da gestão cultural, da comunicação social e da tecnologia da informação;

(...)

Art. 38. Constituem princípios e diretrizes da política de Gestão da Memória do Poder Judiciário, além dos elencados no artigo 30 da presente Resolução: I - favorecimento do uso de novas tecnologias digitais para ampliar a dimensão informativa dos acervos;

II - compartilhamento de técnicas das ciências da informação, arquivologia, biblioteconomia, museologia, história, antropologia e sociologia para agregar valor informativo sobre a instituição e seu papel na sociedade;

III - colaboração e interação entre as unidades de Memória e de Arquivo;

IV - promoção de iniciativas de preservação do patrimônio arquivístico, mobiliário e imobiliário de caráter histórico e cultural do Poder Judiciário e respectiva divulgação;

V - promoção de encontros e seminários para intercâmbio de experiências; e

$\mathrm{VI}$ - registro e divulgação de boas práticas no sítio eletrônico do CNJ. (CONSELHO NACIONAL DE JUSTIÇA, 2020b).

A criação de comissão de Gestão da Memória tem como escopo coordenar as políticas de Gestão Documental e da Memória de cada órgão do Poder Judiciário. Embora muitos tribunais já disponham de comissões semelhantes, trata-se de dispositivo relevante e inovador, pois direciona as funções esperadas pelo CNJ na gestão dessas políticas sem excluir a definição de outras pelo próprio órgão. Além da coordenação das políticas de gestão, são atribuições da Comissão de Gestão da Memória o fomento da interlocução e da cooperação entre as áreas de Arquivo, Museu, Memorial, Biblioteca e Gestão Documental do respectivo Tribunal e a aprovação dos critérios de seleção e organização de seu acervo histórico permanente ${ }^{31}$.

Como corolário das diretrizes, destaca-se a importância da obrigatoriedade de instituição de ambientes físico e virtual de preservação e divulgação de informações relativas à memória, produzidas ou custodiadas pelo órgão, seja por meio de Museu, Memorial ou Centro de Memória, de caráter informativo, educativo e de interesse social. Da mesma forma, há previsão expressa de veiculação do ambiente virtual em espaço permanente no sítio eletrônico do órgão e a preservação do acervo digital relacionado à memória institucional em Repositório Arquivístico Digital Confiável $(\text { RDC-Arq) })^{32}$.

No tocante aos chamados Centros de Memória, tem sido observado o aumento de sua da criação nas esferas públicas e privadas, nos últimos anos, os quais congregam funções atribuídas tradicionalmente aos Arquivos, Bibliotecas e Museus.

${ }^{31}$ Artigo 39, caput e incisos II e III, da Resolução CNJ 324/2020.

${ }^{32} \mathrm{O}$ artigo 40, caput e parágrafos $1^{\circ}$ e $2^{\circ}$, da Resolução CNJ 324/2020. 
Esses Centros de Memória apresentam-se com o duplo caráter de instrumento retrospectivo e prospectivo, apto a estabelecer vínculos entre passado, presente e futuro. Por mais que estejam associados a episódios pontuais de celebração do passado, esses Centros não devem sustentar-se apenas em bases comemorativas, pois o olhar retrospectivo tem também outras funcionalidades mais relevantes. Diante disso, cabe a eles colocar seu acervo à disposição de qualquer demanda, o qual deve ser representativo das múltiplas funções exercidas pelo órgão ao longo do tempo, tanto do ponto de vista endógeno (atividades-meio e atividades-fim), quanto exógeno (injunções de natureza econômica, social e política, que pautaram sua atuação). Portanto, é necessário que o Centro de Memória possa mobilizar os documentos dispersos do órgão e colocá-los à disposição dos usuários internos e externos para consulta e pesquisa. (CAMARGO; GOULART, 2015, p. 99-100).

\title{
6 GUARDA PERMANENTE OU HISTÓRICA
}

Um dos principais objetivos das atividades de Gestão Documental é identificar os processos e documentos da guarda permanente ou histórica, os quais interessam sobremaneira às tarefas da Gestão da Memória. Em relação dessa interdependência e complementaridade entre as duas áreas, que é fundamental e norteadora das funções de cada órgão, a matéria é tratada no presente artigo em destaque e separadamente. Pela sua importância e abrangência, o artigo 29 é a seguir transcrito:

\begin{abstract}
Os documentos e processos de guarda permanente constituem patrimônio cultural nacional e compõem o fundo arquivístico histórico do Poder Judiciário, devendo ser custodiados em locais com condições físicas e ambientais adequadas, preferencialmente do próprio órgão, e disponibilizados para consulta sem colocar em risco sua adequada preservação. (CONSELHO NACIONAL DE JUSTIÇA, 2020b).
\end{abstract}

A documentação de guarda permanente é estruturada em quatro pilares ou grupos principais elencados pelo artigo 30, da Resolução CNJ 324/2020: a) destinação antecipada pelas tabelas ou por outras causas (incisos I, II, VII e XI); b) corte cronológico (inciso VI); c) valor secundário reconhecido pela Comissão Permanente de Avaliação Documental (incisos VIII e IX); d) amostra estatística representativa do conjunto documental destinado à eliminação (inciso $X$ ).

O primeiro grupo contempla os documentos e processos com destinação antecipada de preservação por indicarem situações identificadas como revestidas de valores jurídico, histórico, institucional e cultural. Dele fazem parte, os processos de 
classes, assuntos e movimentos constantes das Tabelas Unificadas ${ }^{33}$, aqueles que ensejam julgamentos com repercussão em outros processos ${ }^{34}$, o inteiro teor de petições iniciais, sentenças, decisões de julgamento de mérito e acórdãos dos processos sujeitos a eliminação com o respectivo trânsito em julgado ${ }^{35}$. Também nesse grupo, estão incluídos os documentos ou conjuntos gravados pelo programa Memórias do Mundo (MoW) da UNESCO. (ARQUIVO NACIONAL, 2018, 2020) ${ }^{36}$.

O segundo refere-se ao corte cronológico, o qual indica que todos os documentos e processos devem ser preservados até determinada data estabelecida previamente. Esse critério é essencial para a preservação da memória de cada ramo do Judiciário, enquanto instituição componente da história do país.

Embora tenha permanecido o reconhecimento da autonomia dos órgãos do Poder Judiciário na sua fixação, mesmo porque as datas de criação e realidades locais são diversas, numa tentativa de padronização mínima, previu-se o ano de 1950 para os Tribunais então existentes. Por óbvio, isso não significa que os órgãos do Poder Judiciário com normativos aprovados com corte cronológico fixados em anos posteriores devam reduzi-los. Ao contrário, trata-se de garantia mínima de preservação do patrimônio arquivístico do Poder Judiciário e a redução de corte cronológico anteriormente estabelecido pelo Tribunal não é o escopo da norma.

No terceiro grupo de definição da guarda permanente, destaca-se a atuação das Comissões Permanentes de Avaliação Documental, que são essenciais para essa tarefa de identificação de valor secundário, que pode ser complexa. Conhecimentos multidisciplinares de seus integrantes são imprescindíveis à adequada avaliação do acervo documental quanto aos seus valores jurídico, institucional, histórico e cultural. À CPAD, cabe também a análise de requerimento fundamentado formulado por

\footnotetext{
${ }^{33}$ Tais critérios constituem padrões mínimos, sem prejuízo de que cada segmento do Poder Judiciário e cada Comissão Permanente de Avaliação Documental existente nos tribunais e órgãos subordinados possam ampliar esse conteúdo, o que também contém previsão expressa no art. 22 , $\S 1^{\circ}$ da Resolução CNJ 324/2020 quanto às temporalidades registradas no Sistema Gestor de Tabelas Processuais do CNJ.

${ }^{4}$ Artigo 30, VII, da Resolução CNJ 324/2020: São de guarda permanente: (...) VII - os processos em que forem suscitados Incidente de Uniformização de Jurisprudência, Arguições de Inconstitucionalidade, Assunção de Competência e aqueles que constituírem precedentes de Súmulas, Recurso Repetitivo e Demandas Repetitivas, o que deverá ser anotado nos sistemas processuais 35 Essa categoria diz respeito aos processos passíveis de eliminação, dos quais se preserva o inteiro teor das decisões judiciais com dois objetivos: manter os elementos representativos do exercício da jurisdição para a história do respectivo órgão e também garantir o exercício do direito de certidão.

36 O Programa Memórias do Mundo (MoW) instituído pela UNESCO tem como escopo promover o patrimônio documental (arquivístico e bibliográfico), garantindo a preservação do patrimônio mundial e incentivando iniciativas nacionais e regionais. No Brasil, no período de 2007 a 2018, constam oito acervos relacionados ao Poder Judiciário, conforme listagem de Bens de Patrimônio Brasileiro nominados no Registro Nacional do Brasil do Programa Memória do Mundo - MOW da Unesco.
} 
magistrado ou entidade de caráter histórico, cultural e universitário para preservação de documentos e processos relacionados aos principais eventos históricos nacionais ou regionais.

No quarto e último critério, está a amostra estatística representativa, que é extraída do universo dos documentos destinados à eliminação, constituindo cautela complementar para preservar parcela significativa da documentação não selecionada pelos demais critérios, mas que também pode ser importante como fonte da cultura nacional.

Quanto à documentação administrativa, serão de guarda permanente aquelas previamente indicadas na Tabela de Temporalidade própria e as aptas a indicarem a história da instituição e seus principais acontecimentos como atos normativos e de ajuste $^{37}$. Sobre essa documentação, também há aplicação de corte cronológico e atuação da CPAD para avaliação.

Portanto, a documentação de guarda permanente ou histórica deve ser selecionada a partir de criteriosa avaliação e custodiada em locais com condições físicas e ambientais adequadas para garantir sua conservação. Relevante que se garanta o acesso a essa documentação, importante fonte de pesquisa, sem colocar em risco sua preservação. Para que tal objetivo seja alcançado, há necessidade de estreita relação entre as atividades de Gestão Documental e Gestão da Memória nos diversos órgãos do Poder Judiciário.

\section{CONSIDERAÇÕES FINAIS}

Diante do exposto, apresentamos as seguintes considerações e perspectivas acerca da Gestão Documental e da Gestão da Memória do Poder Judiciário:

1. Na sua missão de aperfeiçoamento do sistema judiciário brasileiro, o Conselho Nacional de Justiça criou o Programa Nacional de Gestão Documental e Memória do Poder Judiciário (Proname), em 2008, com o objetivo de conferir garantia aos direitos e deveres relacionados ao acesso à informação e à preservação e divulgação das fontes de cultura nacional produzidas ou acumuladas no exercício das atribuições jurisdicionais e administrativas por seus vários órgãos. Da estrutura do Proname, fazem parte a Comissão Permanente de Gestão Documental e de Memória do Poder Judiciário, composta por Conselheiros do CNJ, e o Comitê integrado por

${ }^{37}$ Artigo 30, incisos IV e V, da Resolução CNJ 324/2020. 
representantes de todos os segmentos da Justiça, CNJ e Conarq. O Programa foi regrado inicialmente por meio da Recomendação CNJ 37/2011, com enfoque na gestão documental, e evoluiu com a edição da Recomendação CNJ 46/2013, as quais tiveram grande importância e alcance nacional ao orientarem a implementação das respectivas políticas dos Tribunais.

2. Consideráveis avanços na disciplina da matéria ocorreram com as edições da Resolução CNJ 316/2020, instituindo o Dia da Memória do Poder Judiciário (10 de maio) e da Resolução CNJ 324/2020, reorganizando todo o Programa em substituição à Recomendação anterior. Dotada de caráter obrigatório, a Resolução, ao estabelecer princípios, diretrizes e regras, representa reforço fundamental ao Proname, trazendo maior embasamento para a implantação e execução de políticas de Gestão de Documentos, inclusive Digitais, além da introdução da disciplina, pela primeira vez, da Gestão da Memória do Poder Judiciário.

3. A formulação de políticas adequadas de Gestão Documental possibilita o descarte seguro dos processos e documentos, que tenham cumprido integralmente sua finalidade, com considerável economia de recursos humanos e materiais utilizados para seu armazenamento, permitindo a seleção da documentação de guarda permanente ou histórica, que integra o Patrimônio arquivístico e cultural da instituição.

4. Com a regulamentação da Gestão da Memória, reconhece-se a importância dos Patrimônios arquivístico, mobiliário, imobiliário e imaterial do Poder Judiciário como parte integrante do Patrimônio Cultural brasileiro, de modo que cabe a cada órgão, com o apoio dos respectivos juízes, servidores e comunidade, promover e proteger esse Patrimônio.

5. As políticas de Gestão da Memória, nas quais também se inserem as ações e iniciativas previstas para a celebração do Dia da Memória (10 de Maio), contribuem para a consolidação da identidade do Poder Judiciário perante a sociedade, como garantidor da cidadania e dos direitos, além de pacificador social. Permitem maior visibilidade da necessidade de preservação e promoção da história e da memória do Poder Judiciário, mostrando a relevância do resgate, conservação, valorização e difusão de seus acervos custodiados em Arquivos, Bibliotecas, Centros Culturais, Memoriais e Museus, que fazem parte do Patrimônio Cultural brasileiro e são importantes fontes de pesquisa científica de variadas áreas. Por fim, possibilitam o fortalecimento da noção de pertencimento de juízes e servidores à instituição. 
6. Para que haja avanços nessas ações, é importante a coordenação eficaz das políticas de Gestão da Memória não apenas por parte do CNJ, mas também por cada órgão do Poder Judiciário. No caso dos Tribunais, é necessária a criação e efetiva atuação da Comissão de Gestão de Memória, prevista pela Resolução CNJ $324 / 2020$, que deve congregar todos os espaços concernentes da instituição em ações conjuntas e colaborativas em prol da memória. Outro grande desafio dessa área é o tratamento da documentação de guarda permanente ou histórica por meio de descrição arquivística, adequada conservação, desenvolvimento de instrumentos de pesquisa, disponibilização de acesso e difusão.

7. Um dos grandes desafios por parte dos órgãos do Poder Judiciário é a adoção de Repositório Arquivístico Digital Confiável (RDC-Arq), projetado para manter os dados em padrões adequados de preservação digital e acesso em longo prazo. Fundamentado também na Carta de Preservação Digital da UNESCO, o RDC-Arq é essencial não apenas para a memória institucional de cada Tribunal, mas também para a memória coletiva das gerações futuras.

8. Para a formulação e execução das políticas de Gestão Documental e Gestão da Memória nos diversos ramos do Poder Judiciário, é essencial a atuação transdisciplinar, inclusive no âmbito das Comissões Permanentes de Avaliação Documental, com a necessária participação de profissionais graduados em Arquivologia, História e Direito, assim como recomendáveis outras formações relacionadas, como Biblioteconomia, Museologia, Comunicação Social, Ciências Sociais, Tecnologia da Informação e de tantos outros ramos do conhecimento.

9. Com a menção expressa à participação de magistrados no Comitê do Proname do CNJ, na Comissão Gestora de Memória e na Comissão Permanente de Avaliação Documental dos Tribunais, esperam-se benefícios tanto na formulação e execução das políticas de Gestão Documental e da Memória, quanto no próprio exercício da jurisdição.

10. Os dois eixos do Proname são interdependentes e complementares entre si, pois não existe Gestão Documental sem Gestão da Memória, já que a primeira separa, no processo de avaliação, os documentos sujeitos a eliminação daqueles de guarda permanente ou histórica, indicando o patrimônio arquivístico da instituição. De outro lado, tampouco existe Gestão da Memória sem Gestão Documental, pois as iniciativas de preservação dos bens históricos da instituição não podem prescindir daqueles arquivísticos, que devem receber o adequado tratamento para garantia de 
acesso e difusão aos pesquisadores e à sociedade. Portanto, a atuação integrada de ambas as áreas, de forma cooperativa e com interlocução efetiva, é essencial para realização dos objetivos de salvaguarda do Patrimônio Cultural.

11. Desafios são colocados aos diversos órgãos do Poder Judiciário, aos quais se impõe a elaboração ou adaptação de seus Programas de Gestão Documental e de Gestão da Memória à luz da referida Resolução CNJ 324/2020. Ao Conselho Nacional de Justiça, além das atribuições próprias no âmbito do Proname, caberá atualizar seu Manual de Gestão Documental, elaborar seu primeiro Manual de Gestão da Memória, apoiar os diversos órgãos na formulação de suas políticas, fomentar a capacitação e coordenar a interoperabilidade dos sistemas de Gestão Documental e da Memória dos diversos Tribunais.

12. Por conseguinte, em razão da relevância do tema, sugere-se incluir a formulação e execução de políticas de Gestão Documental e da Memória nos Planejamentos Estratégicos Nacional do Poder Judiciário e de seus diversos segmentos, de modo a promover a construção de uma Justiça transparente, inclusiva, responsável e eficaz também no tocante ao acesso à informação e ao Patrimônio Cultural, conforme a Constituição Federal, as normas internacionais e o Objetivo 16 da Agenda 2030 da Organização das Nações Unidas para o Desenvolvimento Sustentável.

\section{REFERÊNCIAS}

ARQUIVO NACIONAL (Brasil). Bens de patrimônio brasileiros nominados no registro nacional do Brasil do programa memória do mundo - MOW da UNESCO. [Rio de Janeiro]: Arquivo Nacional, 2018. Disponível em:

http://mow.arquivonacional.gov.br/images/pdf/MOW_tabela_acervos_2007_2018_co m_links.pdf. Acesso em: 27 jul. 2020.

ARQUIVO NACIONAL (Brasil). Comitê nacional do Brasil do programa memória do mundo da UNESCO. [Rio de Janeiro]: Arquivo Nacional, 2020. Disponível em: http://mow.arquivonacional.gov.br/index.php/2015-03-20-10-44-

04/apresentacao.htm. Acesso em: 27 jul. 2020.

BELLOTTO, Heloísa Liberalli. Arquivos permanentes: tratamento documental. 4. ed. Rio de Janeiro: FGV, 2006.

BÖTTCHER, Carlos Alexandre. Dia da memória do poder judiciário. Lex Cult Revista do CCJF, [S. I.], v. 4, n. 1, p. 14-33, 2020a. Disponível em: http://lexcultccjf.trf2.jus.br/index.php/LexCult/article/view/342. Acesso em: 08 jul. 2020. 
BÖTTCHER, Carlos Alexandre. Dia da memória do poder judiciário: a Resolução CNJ 316/2020. Consultor Jurídico, p. 1-9, 2020c. Disponível em: https://www.conjur.com.br/2020-mai-02/opiniao-dia-memoria-poder-judiciarioresolucao-cnj-3162020. Acesso em: 08 jul. 2020.

BÖTTCHER, Carlos Alexandre. Dia da memória do poder judiciário: objetivos da Resolução CNJ no 316/2020. Revista Justiça e Cidadania, n. 237, p. 1-3, 2020 b. Disponível em: https://www.editorajc.com.br/dia-da-memoria-do-poder-judiciario/. Acesso em: 08 jul. 2020.

BÖTTCHER, Carlos Alexandre. Resolução CNJ 324/2020: gestão documental e da memória do poder judiciário. Consultor Jurídico, p. 1-9, 2020d. Disponível em: https://www.conjur.com.br/2020-jul-14/carlos-bottcher-resolucao-cnj-3242020. Acesso em: 23 jul. 2020.

BRASIL. [Constituição (1988)]. Constituição da República Federativa do Brasil de 1988. Brasília, DF: Presidência da República, 1988. Disponível em: http://www.planalto.gov.br/ccivil_03/constituicao/constituicao.htm. Acesso em: 08 jul. 2020.

BRASIL. Decreto no 10.278, de 18 de março de 2020. Regulamenta o disposto no inciso X do caput do art. 3 o da Lei no 13.874, de 20 de setembro de 2019, e no art. 2-A da Lei oㅡ 12.682, de 9 de julho de 2012, para estabelecer a técnica e os requisitos para a digitalização de documentos públicos ou privados, a fim de que os documentos digitalizados produzam os mesmos efeitos legais dos documentos originais. Brasília, DF: Presidência da República, 2020. Disponível em: http://www.planalto.gov.br/ccivil_03/_ato2019-2022/2020/decreto/D10278.htm. Acesso em: 28 jul. 2020.

BRASIL. Decreto no 10.148, de 2 de dezembro de 2019. Institui a Comissão de Coordenação do Sistema de Gestão de Documentos e Arquivos da administração pública federal, dispõe sobre a Comissão Permanente de Avaliação de Documentos, as Subcomissões de Coordenação do Sistema de Gestão de Documentos e Arquivos da Administração Pública Federal e o Conselho Nacional de Arquivos, e dá outras providências. Brasília, DF: Presidência da República, 2019a. Disponível em: http://www.planalto.gov.br/ccivil_03/_ato2019-2022/2019/decreto/D10148.htm. Acesso em: 27 jul. 2020.

BRASIL. Decreto no 4.073, de 3 de janeiro de 2002. Regulamenta a Lei № 8.159, de 8 de janeiro de 1991, que dispõe sobre a política nacional de arquivos públicos e privados. Brasília, DF: Presidência da República, 2002. Disponível em:

http://www.planalto.gov.br/ccivil_03/decreto/2002/D4073.htm. Acesso em: 22 jul. 2020.

BRASIL. Lei no 11.419, de 19 de dezembro de 2006. Dispõe sobre a informatização do processo judicial; altera a Lei no 5.869 , de 11 de janeiro de 1973 - Código de Processo Civil; e dá outras providências. Brasília, DF: Presidência da República, 2006. Disponível em: http://www.planalto.gov.br/ccivil_03/_ato20042006/2006/lei/l11419.htm. Acesso em: 27 jul. 2020. 
BRASIL. Lei no 12.527, de 18 de novembro de 2011. Regula o acesso a informações previsto no inciso XXXIII do art. $5^{\circ}$, no inciso II do $\S 3^{\circ}$ do art. 37 e no $\S$ $2^{\circ}$ do art. 216 da Constituição Federal; altera a Lei $n^{\circ} \mathbf{8}$ 8.112, de 11 de dezembro de 1990; revoga a Lei no 11.111, de 5 de maio de 2005, e dispositivos da Lei no 8.159, de 8 de janeiro de 1991; e dá outras providências. Brasília, DF: Presidência da República, 2011. Disponível em: http://www.planalto.gov.br/ccivil_03/_ato20112014/2011/lei/l12527.htm. Acesso em: 27 jul. 2020.

BRASIL. Lei no 12.682, de 9 de julho de 2012. Dispõe sobre a elaboração e o arquivamento de documentos em meios eletromagnéticos. Brasília, DF: Presidência da República, 2012. Disponível em: http://www.planalto.gov.br/ccivil_03/_ato2011 2014/2012/lei/l12682.htm. Acesso em: 20 jul. 2020.

BRASIL. Lei no 13.874, de 20 de setembro de 2019. Institui a Declaração de Direitos de Liberdade Econômica; estabelece garantias de livre mercado; altera as Leis nos 10.406, de 10 de janeiro de 2002 (Código Civil), 6.404, de 15 de dezembro de 1976, 11.598, de 3 de dezembro de 2007, 12.682, de 9 de julho de 2012, 6.015, de 31 de dezembro de 1973, 10.522, de 19 de julho de 2002, 8.934, de 18 de novembro 1994, o Decreto-Lei no 9.760, de 5 de setembro de 1946 e a Consolidação das Leis do Trabalho, aprovada pelo Decreto-Lei no 5.452, de 1ㅇ de maio de 1943; revoga a Lei Delegada № 4, de 26 de setembro de 1962, a Lei № 11.887, de 24 de dezembro de 2008, e dispositivos do Decreto-Lei no 73, de 21 de novembro de 1966; e dá outras providências. Brasília, DF: Presidência da República, 2019b. Disponível em: http://www.planalto.gov.br/ccivil_03/_ato2019-2022/2019/lei/L13874.htm. Acesso em: 28 jul. 2020.

BRASIL. Lei no 5.869, de 11 de janeiro de 1973. Código de Processo Civil. Brasília, DF: Presidência da República, 1973. Disponível em: http://www.planalto.gov.br/ccivil_03/leis//5869impressao.htm. Acesso em: 20 jul. 2020.

BRASIL. Lei no 6.246, de 7 de outubro de 1975. Suspende a vigência do artigo 1.215 do Código de Processo Civil. Brasília, DF: Presidência da República, 1975. Disponível em: http://www.planalto.gov.br/ccivil_03/leis/L6246.htm. Acesso em: 20 jul 2020.

BRASIL. Lei no 7.627, de 10 de novembro de 1987. Dispõe sobre a eliminação de autos findos nos órgãos da Justiça do Trabalho, e dá outras providências. Brasília, DF: Presidência da República, 1987. Disponível em: http://www.planalto.gov.br/ccivil_03/leis/1980-1988/L7627.htm. Acesso em: 28 jul. 2020.

BRASIL. Lei no 8.159, de 8 de janeiro de 1991. Dispõe sobre a política nacional de arquivos públicos e privados e dá outras providências. Brasília, DF: Presidência da República, 1991. Disponível em: http://www.planalto.gov.br/ccivil_03/Leis/L8159.htm. Acesso em: 27 jul. 2020.

BRASIL. Lei no 9.605, de 12 de fevereiro de 1998. Dispõe sobre as sanções penais e administrativas derivadas de condutas e atividades lesivas ao meio ambiente, e dá outras providências. Brasília, DF: Presidência da República, 1998. Disponível em: http://www.planalto.gov.br/ccivil_03/leis/19605.htm. Acesso em: 27 jul. 2020. 
BRASIL. Lei no 9.868, de 10 de novembro de 1999. Dispõe sobre o processo e julgamento da ação direta de inconstitucionalidade e da ação declaratória de constitucionalidade perante o Supremo Tribunal Federal. Brasília, DF: Presidência da República, 1999a. Disponível em:

http://www.planalto.gov.br/ccivil_03/leis//9868.htm. Acesso em: 22 jul. 2020.

BRASIL. Lei no 9.882, de 3 de dezembro de 1999. Dispõe sobre o processo e julgamento da argüição de descumprimento de preceito fundamental, nos termos do $\S 10$ do art. 102 da Constituição Federal. Brasília, DF: Presidência da República, 1999b. Disponível em: http://www.planalto.gov.br/ccivil_03/leis/19882.htm. Acesso em: 22 jul. 2020.

CAMARGO, Ana Maria de Almeida; GOULART, Silvana. Centros de memória: uma proposta de definição. São Paulo: SESCSP, 2015.

CONSELHO NACIONAL DE ARQUIVOS (Brasil). Ata da 51aㅜ reunião plenária ordinária do Conselho Nacional de Arquivos (CONARQ), de 12 de dezembro de 2008. [Rio de Janeiro]: CONARQ, 2008a. Disponível em:

http://www.conarq.gov.br/images/Atas/Ata_51_reuniao_plenaria_ordinaria_conarq_2 0081212.pdf. Acesso em: 27 jul. 2020.

CONSELHO NACIONAL DE ARQUIVOS (Brasil). Resolução CONARQ no 26, de 6 de maio de 2008. Estabelece diretrizes básicas de gestão de documentos a serem adotadas nos arquivos do Poder Judiciário [Rio de Janeiro]: Presidência, 2008b. Disponível em: http://conarq.gov.br/resolucoes-do-conarq/268-resolucao-n-26,-de06-de-maio-de-2008.html. Acesso em: 23 jul. 2020.

CONSELHO NACIONAL DE ARQUIVOS (Brasil). Resolução CONARQ no 43, de 4 de setembro de 2015. Estabelece diretrizes para a implementação de Repositórios Arquivísticos Digitais Confiáveis para o arquivamento e manutenção de documentos arquivísticos digitais em suas fases corrente, intermediária e permanente, dos órgãos e entidades integrantes do Sistema Nacional de Arquivos - SINAR [Rio de Janeiro: Presidência, 2015. Disponível em: http://www.conarq.gov.br/resolucoes-doconarg/335-resolucao-n-43-de-04-de-setembro-de-2015.html. Acesso em: 29 jul. 2020.

CONSELHO NACIONAL DE JUSTIÇA (Brasil). Campanha dia da memória em 2020: publicações em redes sociais. CNJ, [S. I.], 2020e. Disponível em:

https://www.cnj.jus.br/programas-e-acoes/gestao-documental/memoria-do-poderjudiciario/dia-da-memoria/campanha-dia-da-memoria-em-2020/campanha-dia-damemoria-em-2020-publicacoes-em-redes-sociais/. Acesso em: 23 jul. 2020.

CONSELHO NACIONAL DE JUSTIÇA (Brasil). Dia da memória do poder judiciário: relatório consolidado. CNJ, [S. I.], 2020d. Disponível em: https://www.cnj.jus.br/wpcontent/uploads/2020/06/Relat\%C3\%B3rio-Mat\%C3\%A9rias-Dia-daMem\%C3\%B3ria-02062020-18h00.pdf. Acesso em: 28 jul. 2020.

CONSELHO NACIONAL DE JUSTIÇA (Brasil). Diagnóstico dos arquivos do poder judiciário: relatório Proname. Brasília, DF: CNJ, 2020a. Disponível em: 
https://www.cnj.jus.br/wp-content/uploads/2020/05/Relatorio-Proname-revisado1.pdf. Acesso em: 08 jul. 2020.

CONSELHO NACIONAL DE JUSTIÇA (Brasil). Manual de gestão documental do poder judiciário. Brasília, DF: CNJ, 2011b. Disponível em:

https://www.cnj.jus.br/wp-

content/uploads/2014/02/manual_gestao_documental_poder\%20judiciario.pdf.

Acesso em: 09 jul. 2020.

CONSELHO NACIONAL DE JUSTIÇA (Brasil). Moreq-Jus. [Brasília, DF]: CNJ, 2009b. Disponível em: https://www.cnj.jus.br/programas-e-acoes/gestaodocumental/sistemamoreq-jus/. Acesso em: 28 jul. 2020.

CONSELHO NACIONAL DE JUSTIÇA (Brasil). Portaria no 105, de 18 de setembro de 2015. Constitui Comitê do Programa Nacional de Gestão Documental e Memória do Poder Judiciário - Proname. [Brasília, DF]: Presidência, 2015b. Disponível em: https://atos.cnj.jus.br/files//portaria/portaria_105_18092015_24092015162330.pdf. Acesso em: 24 abr. 2020.

CONSELHO NACIONAL DE JUSTIÇA (Brasil). Portaria no 159, de 11 de dezembro de 2018. Altera a composição do Comitê do Programa Nacional de Gestão Documental e Memória do Poder Judiciário - Proname. [Brasília, DF]: Presidência, 2018. Disponível em:

https://atos.cnj.jus.br/files/compilado164215201911225dd80fe73ecaa.pdf. Acesso em: 07 jul. 2020.

CONSELHO NACIONAL DE JUSTIÇA (Brasil). Portaria no 616, de 10 de setembro de 2009. Constitui Comitê do Programa Nacional de Gestão Documental e Memória do Poder Judiciário - Proname. [Brasília, DF]: Presidência, 2009a. Disponível em: https://atos.cnj.jus.br/files//portaria/portaria_616_10092009_18102012212627.pdf.

Acesso em: 24 abr. 2020.

CONSELHO NACIONAL DE JUSTIÇA (Brasil). Resolução n²15, de 16 de dezembro de 2015. Dispõe, no âmbito do Poder Judiciário, sobre o acesso à informação e a aplicação da Lei 12.527, de 18 de novembro de 2011. [Brasília, DF]: Presidência, 2015a. Disponível em: https://atos.cnj.jus.br/atos/detalhar/2236. Acesso em: 20 jul. 2020.

CONSELHO NACIONAL DE JUSTIÇA (Brasil). Resolução n²96, de 19 de setembro de 2019. Cria e revoga Comissões Permanentes no âmbito do Conselho Nacional de Justiça. [Brasília, DF]: Presidência, 2019. Disponível em: https://atos.cnj.jus.br/atos/detalhar/3038. Acesso em: 20 jul. 2020.

CONSELHO NACIONAL DE JUSTIÇA (Brasil). Resolução no 316, de 22 de abril de 2020. Institui o Dia da Memória do Poder Judiciário e dá outras providências.

[Brasília, DF]: Presidência, 2020c. Disponível em:

https://atos.cnj.jus.br/files/original205237202004295ea9e91534551.pdf. Acesso em: 8 jul. 2020.

CONSELHO NACIONAL DE JUSTIÇA (Brasil). Resolução n 324, de $\mathbf{3 0}$ de junho de 2020. Institui diretrizes e normas de Gestão de Memória e de Gestão Documental 
e dispõe sobre o Programa Nacional de Gestão Documental e Memória do Poder Judiciário - Proname. [Brasília, DF]: Presidência, 2020b. Disponível em: https://atos.cnj.jus.br/atos/detalhar/3376. Acesso em: 19 jul. 2020.

CONSELHO NACIONAL DE JUSTIÇA (Brasil). Recomendação no 37, de 15 de agosto de 2011. Recomenda aos Tribunais a observância das normas de funcionamento do Programa Nacional de Gestão Documental e Memória do Poder Judiciário - Proname e de seus instrumentos. [Brasília, DF]: Presidência, 2011a. Disponível em: https://atos.cnj.jus.br/atos/detalhar/846. Acesso em: 07 jul. 2020.

CONSELHO NACIONAL DE JUSTIÇA (Brasil). Recomendação no 43, de 17 de dezembro de 2013. Altera a Recomendação n. 37, de 15 de agosto de 2011. Brasília, DF: Presidência, 2013. Disponível em: https://atos.cnj.jus.br/atos/detalhar/1991. Acesso em: 07 jul. 2020.

CONSELHO NACIONAL DE JUSTIÇA (Brasil). Resolução no 65, de 16 de dezembro de 2008. Dispõe sobre a uniformização do número dos processos nos órgãos do Poder Judiciário e dá outras providências. [Brasília, DF]: Presidência, 2008b. Disponível em: https://atos.cnj.jus.br/atos/detalhar/atosnormativos?documento=119. Acesso em: 20 jul. 2020.

CONSELHO NACIONAL DE JUSTIÇA (Brasil). Resolução no 91, de 29 de setembro de 2009. Institui o Modelo de Requisitos para Sistemas Informatizados de Gestão de Processos e Documentos do Poder Judiciário e disciplina a obrigatoriedade da sua utilização no desenvolvimento e manutenção de sistemas informatizados para as atividades judiciárias e administrativas no âmbito do Poder Judiciário. [Brasília, DF]: Presidência, 2009b. Disponível em: https://atos.cnj.jus.br/files/resolucao_91_29092009_04042019141353.pdf. Acesso em: 08 jul. 2020.

CONSELHO NACIONAL DE JUSTIÇA (Brasil). Termo de cooperação técnica no 22/2008. Termo de cooperação técnica que entre si celebram o Conselho Nacional de Justiça e o Conselho Nacional de Arquivos, para fins que especifica (Processo $\mathrm{n}^{\circ}$ 333.818). Brasília, DF: CNJ, 2008a. Disponível em: https://www.cnj.jus.br/wpcontent/uploads/2019/11/TCOT_022_2008.pdf. Acesso em: 19 jul. 2020.

DORTIER, Jean-François. Dicionário de ciências humanas. Tradução: Márcia Valéria Martinez de Aguiar. São Paulo: Martins Fontes, 2010.

FLORES, Daniel; ROCCO, B. C. B.; SANTOS, H. M. Cadeia de custódia para documentos arquivísticos digitais. Acervo, v. 29, n. 2, p. 117-132, 2016. Disponível em:

http://revista.arquivonacional.gov.br/index.php/revistaacervo/article/view/717/732. Acesso em: 08 jul. 2020.

GAVA, Tânia Barbosa Salles; FLORES, Daniel. Repositórios arquivísticos digitais confiáveis (RDC-Arq) como plataforma de preservação digital em um ambiente de gestão arquivística. Informação e Informação, [S. I.], v. 25, n. 2, p. 74-99, 2020. Disponível em: http://www.uel.br/revistas/uel/index.php/informacao/article/view/38411. Acesso em: 07 jul. 2020. 
HALBWACHS, Maurice. A memória coletiva. Tradução: Laurent Léon Schaffter. São Paulo: Revista dos Tribunais, 1990.

HENDGES, Carla Evelise Justino; SLIWKA, Ingrid Schroder. O direito constitucional à informação, a Lei 12.527/2011 e a gestão documental no Poder Judiciário. Revista Autos e Baixas, Porto Alegre, v. 1, n. 1, p. 1-26, 2013. Disponível em: http://revistadigital.jfrs.jus.br/revista/index.php/revista_autos_e_baixas/article/view/7. Acesso em: 25 jul. 2020.

IBRAM. Semana nacional de museus. Instituto Brasileiro de Museus, Brasília, DF, 2020. Disponível em: https://www.museus.gov.br/acessoainformacao/acoes-eprogramas/semana-nacional-de-museus/. Acesso em: 23 jul. 2020.

IPHAN. Declaração do México: conferência mundial sobre as políticas culturais. [Brasília, DF]: IPHAN, 1985. Disponível em: http://portal.iphan.gov.br/uploads/ckfinder/arquivos/Declaracao\%20do\%20Mexico\%2 01985.pdf. Acesso em: 26 jul. 2020.

LE GOFF, Jacques. História e memória. Tradução: Bernardo Leitão. Campinas: Unicamp, 2003.

RONDÔNIA (Estado). Governo do Estado de Rondônia. Lei no 783, de 03 de julho de 1998. Autoriza o Poder Judiciário do Estado de Rondônia a inutilizar processos judiciais arquivados e findos. [Pedrinhas, RO]: Governo do Estado, 1998. Disponível em:

https://sapl.al.ro.leg.br/media/sapl/public/normajuridica/1998/1306/1306_texto_integr al.pdf. Acesso em: 28 jul. 2020.

SCHELLENBERG, Theodore R. Arquivos modernos: princípios e técnicas. Tradução: Nilza Teixeira Soares. 6. ed. Rio de Janeiro: FGV, 2006.

SLIWKA, Ingrid Schroder. Considerações sobre a gestão documental dos autos findos. Revista CEJ, Brasília, v. 15, p. 32-48, 2011b. Disponível em: https://revistacej.cjf.jus.br/revcej/article/view/1513/1470. Acesso em: 25 jul. 2020.

SLIWKA, Ingrid Schroder. Gestão de documentos judiciais à luz da Recomendação no 37/2011-CNJ. Revista de Doutrina da 4⿳亠丷厂 Região, Porto Alegre, n. 45, p. 1-50, 2011a. Disponível em:

https://revistadoutrina.trf4.jus.br/artigos/edicao045/ingrid_sliwka.html. Acesso em: 25 jul. 2020.

SUPERIOR TRIBUNAL DE JUSTIÇA (Brasil). Tribunal institui política de preservação de documentos digitais. STJ, Brasília, DF, 2019. Disponível em: http://www.stj.jus.br/sites/portalp/Paginas/Comunicacao/Noticias/Tribunal-instituipolitica-de-preservacao-de-documentos-digitais.aspx. Acesso em: 10 jul. 2020.

SUPREMO TRIBUNAL FEDERAL (Brasil). ADI no 1919, São Paulo. Destruição física dos autos de processos judiciais arquivados há mais de cinco anos em primeira instância. Recorrente: Procurador-Geral da República. Recorrido: Conselho Superior da Magistratura do Estado de São Paulo. Relatora: Min. Ellen Gracie, 7 de 
abril de 2003. Disponível em:

https://jurisprudencia.stf.jus.br/pages/search/sjur14923/false. Acesso em: 26 jul. 2020.

TRIBUNAL DE JUSTIÇA (Distrito Federal). TJDFT e IBICT assinam acordo para transferência de tecnologia. Tribunal de Justiça do Distrito Federal e dos Territórios, Brasília, DF, 2018. Disponível em: https://www.tjdft.jus.br/institucional/imprensa/noticias/2018/outubro/tjdft-e-ibictassinam-acordo-para-transferencia-de-tecnologia. Acesso em: 10 jul. 2020.

UNESCO. Charter on the preservation of digital heritage. Paris: UNESCO, 2003b. Disponível em: http://portal.unesco.org/en/ev.php-

URL_ID=17721\&URL_DO=DO_TOPIC\&URL_SECTION=201.html. Acesso em: 22 jul. 2020.

UNESCO. Convenção para a proteção do patrimônio mundial cultural e ambiental. Paris: UNESCO, 1972. Disponível em:

https://whc.unesco.org/archive/convention-pt.pdf. Acesso em: 22 jul. 2020.

UNESCO. Convenção para a salvaguarda do patrimônio cultural imaterial. Paris: UNESCO, 2003a. Disponível em: https://ich.unesco.org/doc/src/00009-PTPortugal-PDF.pdf. Acesso em: 22 jul. 2020.

UNESCO. Declaração de Varsóvia: cultura, memória e identidades. Varsóvia: UNESCO, 2011. Disponível em:

http://www.unesco.org/new/fileadmin/MULTIMEDIA/HQ/Cl/Cl/pdf/mow/Warsaw_decl aration.pdf. Acesso em: 22 jul. 2020.

UNESCO. Declaração universal sobre arquivos. Oslo: UNESCO, 2010. Disponível em: https://www.ica.org/sites/default/files/ICA_2010_Universal-Declaration-onArchives_PT.pdf. Acesso em: 22 jul. 2020.

UNESCO. Recommendation concerning the preservation of, and access to, documentary heritage including in digital form. Paris: UNESCO, 2015a.

Disponível em: http://portal.unesco.org/en/ev.php-

URL_ID=49358\&URL_DO=DO_TOPIC\&URL_SECTION=201.html. Acesso em: 22 jul. 2020.

UNESCO. Recommendation concerning the protection and promotion of museums and collections, their diversity and their role in society. Paris:

UNESCO, 2015b. Disponível em: http://portal.unesco.org/en/ev.php-

URL_ID=49357\&URL_DO=DO_TOPIC\&URL_SECTION=201.html. Acesso em: 22 jul. 2020.

UNESCO. Recommendation for the safeguarding and preservation of moving images. Belgrado: UNESCO, 1980. Disponível em:

http://portal.unesco.org/en/ev.php-

URL_ID=13139\&URL_DO=DO_TOPIC\&URL_SECTION=201.html. Acesso em: 22 jul. 2020. 